\title{
BMJ
}

\section{Alternative approaches to endoscopic ablation for benign enlargement of the prostate: systematic review of randomised controlled trials}

\author{
Tania Lourenco, research fellow, ${ }^{1}$ Robert Pickard, senior clinical lecturer, ${ }^{2}$ Luke Vale, professor of health \\ technology assessment, ${ }^{1,3}$ Adrian Grant, professor of health services research, ${ }^{1}$ Cynthia Fraser, information \\ officer, ${ }^{1}$ Graeme MacLennan, statistician, ${ }^{1}$ James N'Dow, professor of urology, ${ }^{4}$ and the Benign Prostatic \\ Enlargement team
}

\begin{abstract}
Health Services Research Unit, Institute of Applied Health Sciences, University of Aberdeen

${ }^{2}$ Department of Urology, School of Surgical and Reproductive

Sciences, Newcastle University, Newcastle upon Tyne

${ }^{3}$ Health Economics Research Unit, Institute of Applied Health

Sciences, University of Aberdeen

${ }^{4}$ Academic Urology Unit, Institute

of Applied Health Sciences,

University of Aberdeen, AB25 2ZD

Correspondence to: J N'Dow

j.ndow@abdn.ac.uk
\end{abstract}

doi:10.1136/bmj.39575.517674.BE

\section{ABSTRACT}

Objective To compare the effectiveness and risk profile of newer methods for endoscopic ablation of the prostate against the current standard of transurethral resection.

Design Systematic review and meta-analysis.

Data sources Electronic and paper records in subject area up to March 2006.

Review methods We searched for randomised controlled trials of endoscopic ablative interventions that included transurethral resection of prostate as one of the treatment arms. Two reviewers independently extracted data and assessed quality. Meta-analyses of prespecified outcomes were done using fixed and random effects models and reported using relative risk or weighted mean difference.

Results We identified 45 randomised controlled trials meeting the inclusion criteria and reporting on 3970 participants. The reports were of moderate to poor quality, with small sample sizes. None of the newer technologies resulted in significantly greater improvement in symptoms than transurethral resection at 12 months, although a trend suggested a better outcome with holmium laser enucleation (random effects weighted mean difference $-0.82,95 \%$ confidence interval 1.76 to 0.12$)$ and worse outcome with laser vaporisation (1.49, -0.40 to 3.39). Improvements in secondary measures, such as peak urine flow rate, were consistent with change in symptoms. Blood transfusion rates were higher for transurethral resection than for the newer methods ( $4.8 \% v 0.7 \%)$ and men undergoing laser vaporisation or diathermy vaporisation were more likely to experience urinary retention (6.7\% v $2.3 \%$ and $3.6 \% v 1.1 \%)$. Hospital stay was up to one day shorter for the newer technologies. Conclusions Although men undergoing more modern methods of removing benign prostatic enlargement have similar outcomes to standard transurethral resection of prostate along with fewer requirements for blood transfusion and shorter hospital stay, the quality of current evidence is poor. The lack of any clearly more effective procedure suggests that transurethral resection should remain the standard approach.

\section{INTRODUCTION}

Clinical benign enlargement of the prostate is a syndrome comprising symptoms of the lower urinary tract in conjunction with benign prostatic hypertrophy and usually a reduced peak urinary flow rate. It is highly prevalent among older men, affecting 30\% of those older than 60 and $40 \%$ of those older than $70 .{ }^{1}$ Although the precise relation between symptoms, pathological evidence of hyperplasia, and bladder outlet obstruction is debatable, removal of prostate tissue in men with suspected clinical benign prostatic enlargement generally results in substantial reduction of symptoms, resolution of obstruction, and improved wellbeing.

For many years transurethral resection of the prostate has been the standard endoscopic technique for ablation of benign prostate tissue, and improvements in optics, diathermy, and anaesthesia have reduced treatment related morbidity to a relatively low level. ${ }^{1}$ Despite this, transurethral resection requires technical skill; causes physiological stress, affecting recovery in some men; carries some risks; and does not satisfactorily improve symptoms in all men. ${ }^{2}$ This has encouraged the development of alternative endoscopic procedures using other energy sources, such as lasers to ablate prostate tissue by resection or vaporisation. Ideally, such procedures should have a satisfactory evidence base showing advantage over transurethral resection before generalised introduction. We carried out a systematic review using data from randomised controlled trials to determine whether these newer procedures are better than transurethral resection of the prostate for greater improvements in urinary symptoms or a reduced risk of adverse events such as the need for blood transfusion.

\section{METHODS}

To identify published and unpublished reports of relevant randomised controlled trials we carried out highly sensitive electronic searches of Medline (1966September, week 3, 2006), Embase (1980-2006, week 
Table 1| Summary of baseline characteristics of included studies on alternative approaches to endoscopic ablation for benign enlargement of prostate. Values are means unless stated otherwise

\begin{tabular}{|c|c|c|c|c|c|c|c|}
\hline Study & Comparator with transurethral resection of prostate & No of participants & $\begin{array}{c}\text { Age } \\
\text { (years) }\end{array}$ & Symptom score* & $\begin{array}{c}\text { Urine flow } \\
(\mathrm{Qmax} \mathrm{ml} / \mathrm{s})\end{array}$ & $\begin{array}{l}\text { Residual } \\
\text { volume (ml) }\end{array}$ & $\begin{array}{l}\text { Prostate } \\
\text { size (ml) }\end{array}$ \\
\hline Gupta $2006^{\mathrm{w} 1}$ & Holmium laser enucleation & 50,50 & 66,66 & $23.4,23.3$ & $5.1,4.5$ & 112,84 & 58,60 \\
\hline Kuntz $2004^{\mathrm{w2}}$ & Holmium laser enucleation & 100,100 & 68,69 & $22.1,21.4$ & $4.9,5.9$ & 238,216 & 53,50 \\
\hline Montorsi $2004^{\mathrm{w} 3}$ & Holmium laser enucleation & 52,48 & 65,64 & $21.6,21.9$ & $8.2,7.8$ & 4,4 & 70,56 \\
\hline Westenberg $2004^{\mathrm{w} 4}$ & Holmium laser enucleation & 61,59 & 67,67 & $21.9,23.0$ & $8.9,9.1$ & 88,85 & 44,45 \\
\hline Wilson $2006^{\mathrm{w} 5}$ & Holmium laser enucleation & 30,30 & 71,70 & $26.0,23.7$ & $8.4,8.3$ & 113,126 & 78,70 \\
\hline Bouchier-Hayes $2006^{\text {w6 }}$ & Laser vaporisation & 38,38 & 65,66 & $\mathrm{NR}, \mathrm{NR}$ & $\mathrm{NR}, \mathrm{NR}$ & NR, NR & 42,33 \\
\hline Carter 1999w7 & Laser vaporisation & 95,96 & 68,67 & $20.3,19.8$ & $9.0,9.5$ & 109,135 & 42,42 \\
\hline Keoghane $2000^{\text {w8 }}$ & Laser vaporisation & 72,79 & 69,70 & $19.9,19.4$ & $11.8,11.4$ & $\mathrm{NR}, \mathrm{NR}$ & 55,52 \\
\hline Mottet 1999w9 & Laser vaporisation & 17,13 & 64,67 & $21.7,23.7$ & $8.8,7.7$ & $\mathrm{NR}, \mathrm{NR}$ & 37,34 \\
\hline Sengor $1996^{\text {w10 }}$ & Laser vaporisation & 30,30 & 61,66 & $21.8,22.1$ & $8.7,8.4$ & 110,155 & $N R, N R$ \\
\hline Shingleton $2002^{\text {w11 }}$ & Laser vaporisation & 50,50 & 68,67 & 22,21 & $\mathrm{NR}, \mathrm{NR}$ & $\mathrm{NR}, \mathrm{NR}$ & 32,30 \\
\hline Suvakovic $1996^{\text {w12 }}$ & Laser vaporisation & 10,10 & 63,66 & $18.0,18.8$ & $12.2,11.1$ & 140,162 & 24,22 \\
\hline Tuhkanen $2001^{\text {w13 }}$ & Laser vaporisation & 21,25 & $67 \dagger, 67 \dagger$ & $23 † \ddagger, 19 \dagger \ddagger$ & $7.2,8.5$ & 138,125 & 55,55 \\
\hline Tuhkanen $2003^{\text {w14 }}$ & Laser vaporisation & 26,26 & $68 \dagger, 67 \dagger$ & $18 † \ddagger, 18 \dagger \ddagger$ & $8.3+, 8.6 \dagger$ & $87 \dagger, 83 \dagger$ & $30 \dagger, 28 \dagger$ \\
\hline Van Melick $2003^{\text {w15 }}$ & Laser vaporisation & 45,50 & 67,66 & $18.9,16.8$ & $12.0,11.0$ & 300,350 & 37,37 \\
\hline Zorn $1999^{\text {w16 }}$ & Laser vaporisation & 21,12 & 71,69 & $24.0,24.7$ & $8.7,9.0$ & NR, NR & 30,34 \\
\hline Helke $2001^{\text {w17 }}$ & Transurethral vaporesection & 93,92 & 69,67 & $17.29,18.29$ & $10.8,8.5$ & 76,102 & 49,50 \\
\hline Kupeli $2001^{\text {w18 }}$ & Transurethral vaporesection & 50,50 & 61,59 & $21.6,19.4$ & $9.2,7.9$ & $\mathrm{NR}, \mathrm{NR}$ & 57,58 \\
\hline Gupta $2006^{\mathrm{w} 1}$ & Transurethral vaporesection & 50,50 & 68,66 & $24.9,23.3$ & $4.6,4.5$ & 103,84 & 63,60 \\
\hline Liu $2006^{\text {w19 }}$ & Transurethral vaporesection & 44,32 & 66,65 & $25.6,26.8$ & $6.9,6.9$ & 131,142 & 58,60 \\
\hline Talic $2000^{\text {w20 }}$ & Transurethral vaporesection & 34,34 & 71,70 & $24.9,20.1$ & $7.5,9.1$ & $\mathrm{NR}, \mathrm{NR}$ & 57,52 \\
\hline De Sio $2006^{\text {w21 }}$ & Bipolar transurethral resection & 35,35 & 59,61 & $24.2,24.3$ & $7.1,6.3$ & 80,75 & 52,47 \\
\hline $\operatorname{Kim} 2006^{\mathrm{w} 22}$ & Bipolar transurethral resection & 25,25 & 68,71 & $19.0,18.6$ & $6.5,6.1$ & NR, NR & 53,52 \\
\hline Tefekli $2005^{\mathrm{w} 23}$ & Bipolar transurethral resection & 51,50 & 69,69 & $\mathrm{NR}, \mathrm{NR}$ & $N R, N R$ & $\mathrm{NR}, \mathrm{NR}$ & 54,50 \\
\hline Nuhoğlu $2006^{\text {w24 }}$ & Bipolar transurethral resection & 27,30 & 65,65 & $17.6,17.3$ & $6.9,7.3$ & 96,88 & 47,49 \\
\hline Seckiner $2006^{\text {w25 }}$ & Bipolar transurethral resection & 24,24 & 61,64 & $24.1,23.2$ & $8.5,8.3$ & 88,138 & 49,41 \\
\hline Singh $2005^{\text {w26 }}$ & Bipolar transurethral resection & 30,30 & 69,68 & $20.5,21.6$ & $5.8,5.1$ & 124,136 & NR, NR \\
\hline Çetinkaya $1996^{\text {w27 }}$ & Transurethral vaporisation & 23,23 & 68,62 & $\mathrm{NR}, \mathrm{NR}$ & $N R, N R$ & NR, NR & $48.4,48.8$ \\
\hline Ekengren $2000^{\text {w28 }}$ & Transurethral vaporisation & 26,28 & 70,71 & $25 \dagger, 22 \dagger$ & NR, NR & NR, NR & NR, NR \\
\hline Erdaği $1999^{\text {w29 }}$ & Transurethral vaporisation & 20,20 & 66,64 & $21.5,20.6$ & $4.6,5.1$ & 123,68 & 37,32 \\
\hline Fowler $2005^{\text {w30 }}$ & Transurethral vaporisation & 115,120 & 70,70 & $20.7,20.7$ & $10.1,10.5$ & 181,171 & 54,51 \\
\hline Gallucci $1998^{\text {w31 }}$ & Transurethral vaporisation & 70,80 & $\mathrm{NR}, \mathrm{NR}$ & $18.8,18.2$ & $7.3,8.9$ & 85,65 & 37,37 \\
\hline Gotoh $1999^{\text {w32 }}$ & Transurethral vaporisation & 23,28 & 70,66 & $19.6,18.9$ & $7.3,9.4$ & 57,42 & 57,45 \\
\hline Hammadeh $2003^{\mathrm{w} 33}$ & Transurethral vaporisation & 52,52 & 67,70 & $26.5,26.6$ & $8.9,8.6$ & 131,101 & 32,27 \\
\hline Kaplan 1998 & Transurethral vaporisation & 32,32 & 67,73 & $\mathrm{NR}, \mathrm{NR}$ & $\mathrm{NR}, \mathrm{NR}$ & $\mathrm{NR}, \mathrm{NR}$ & NR, NR \\
\hline Kupeli $1998 a^{\text {w35 }}$ & Transurethral vaporisation & 30,30 & 60,62 & $21.6,19.4$ & $9.2,7.9$ & NR, NR & 52,49 \\
\hline Kupeli 1998b ${ }^{\text {w36 }}$ & Transurethral vaporisation & 30,36 & 66,62 & $13.7,14.6$ & $8.3,8.8$ & $N R, N R$ & 42,44 \\
\hline Nathan $1996^{\text {w37 }}$ & Transurethral vaporisation & 20,20 & 65,69 & $21.9,17.0$ & $10.2,7.2$ & 132,120 & 53,53 \\
\hline Netto $1999^{\text {w38 }}$ & Transurethral vaporisation & 40,38 & 67,65 & $19.6,24.3$ & $7.9,6.8$ & 73,89 & 47,45 \\
\hline Nuhoğlu $2005^{\text {w39 }}$ & Transurethral vaporisation & 37,40 & 64,65 & $17.6,17.3$ & $6.3,5.9$ & 88,95 & 39,39 \\
\hline Patel $1997^{\text {w40 }}$ & Transurethral vaporisation & 6,6 & 66,67 & $23.3,29.6$ & $7.5,10$ & NR, NR & 65,54 \\
\hline Shokeir $1997^{\mathrm{w} 41}$ & Transurethral vaporisation & 35,35 & 68,68 & $26.3,25.1$ & $7.8,6.9$ & 75,77 & 45,49 \\
\hline Wang $2002^{\text {w42 }}$ & Transurethral vaporisation & 97,109 & 71,72 & 20,20 & 7,7 & 1231,120 & $N R, N R$ \\
\hline Van Melick $2003^{\text {w15 }}$ & Transurethral vaporisation & 46,50 & 64,66 & $20.2,16.8$ & 11,11 & 290,350 & 35,37 \\
\hline Fung $2005^{\text {w43 }}$ & Bipolar transurethral vaporesection & 29,31 & 72,73 & $15.8,19.4$ & $\mathrm{NR}, \mathrm{NR}$ & NR, NR & $\mathrm{NR}, \mathrm{NR}$ \\
\hline Dunsmuir $2003^{\text {w44 }}$ & Bipolar transurethral vaporisation & 30,21 & 63,60 & 24,17 & $9.6,10.4$ & 112,96 & 39,42 \\
\hline Hon $2006^{\text {w45 }}$ & Bipolar transurethral vaporisation & 81,79 & 66,68 & 21,21 & 12,12 & 147,182 & 38,40 \\
\hline
\end{tabular}

$\mathrm{NR}=$ not reported. Total number of trials is 45 with 47 relevant comparisons.

*International prostate symptom score or American Urological Association symptom index.

†Median.

‡Danish prostatic symptom score (Dan-PSSI-1). 
38), Medline In-Process (27 September 2006), Biosis (1985-22 September 2006), Science Citation Index (1981-23 September 2006), ISI Proceedings (1990-18 March 2006), Cochrane Controlled Trials Register and Cochrane Database of Systematic Reviews (Cochrane Library, Issue 1, 2006), Database of Abstracts of Reviews of Effectiveness (March 2006), Health Technology Assessments database (March 2006), National Research Register (Issue 1, 2006), Clinical Trials (March 2006), and Current Controlled Trials (March 2006). We also searched the proceedings of recent conferences of the European Association of Urology, American Urological Association, and British Association of Urological Surgeons. We defined ablative endoscopic treatments as those that resulted in

$\begin{array}{llllll}\text { Symptom score at } 12 \text { months } & \begin{array}{l}\text { No in } \\ \text { group Intervention }\end{array} & \text { Mean (SD) } & \text { Noup } & \text { TURP } & \begin{array}{c}\text { Random effects } \\ \text { Weighted mean }\end{array} \\ \text { Mean (SD) } & \text { difference (95\% CI) }\end{array}$

\section{Holmium laser enucleation $v$ TURP}

Westenberg $2004^{\text {w4 }}$
Gupta $2006^{\text {w1 }}$

Kuntz 2004 w2

Montorsi $2004^{\text {w3 }}$

Wilson $2006^{\text {w5 }}$

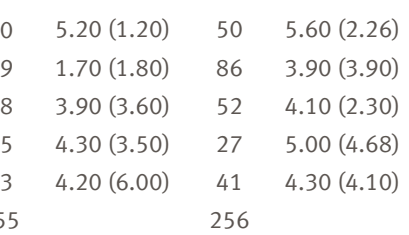

Total (95\% Cl): -0.82 (-1.76 to 0.12) 255 $\mathrm{P}=0.09, \mathrm{I}^{2}=65.8 \%$

\section{Laser vaporisation $\mathbf{v}$ TURP}

Keoghane $2000^{\text {w8 }}$

Van Melick $2003^{\text {w15 }}$

Shingleton $2002^{\text {w11 }}$

Suvakovic $1996^{\text {w12 }}$

$P=0.12,\left.\right|^{2}=55.7 \%$

Transurethral vaporesection $\mathbf{v}$ TURP

$\begin{array}{lr}\text { Gupta } 2006^{\text {w1 }} & 50 \\ \text { Helke } 2001^{\text {w17 }} & 79 \\ \text { Total }(95 \% \mathrm{Cl}):-0.28(-1.01 \text { to } 0.45) & 129 \\ \mathrm{P}=0.45, \mathrm{I}^{2}=0 \% & \end{array}$

Bipolar transurethral resection $\boldsymbol{v}$ TURP Nuhoglu 2006 w24 24

Seckiner $2006^{\text {w25 }}$

$24 \quad 5.40(3.70)$

$8.70(4.10)$

$5.40(1.97)$

$4.66(4.30)$

50

73

123

$5.21(5.10)$
Total $(95 \% \mathrm{Cl}): 1.49(-0.40$ to 3.39$) 138$

immediate removal of tissue, usually by resection or vaporisation, and did not include procedures that caused delayed tissue necrosis, such as microwave and radiofrequency therapy. Searches were not restricted by publication year or language and included conference proceedings and abstracts. We scanned the reference lists of all included studies to identify additional potentially relevant studies. (Full details of the search strategies are available from the authors.) Two reviewers (TL, Angela Coutts, or Susan Wong) independently screened the titles and abstracts of identified papers and obtained full text copies of all potentially relevant studies.

\section{Study selection and study characteristics}

We included randomised controlled trials if they assessed endoscopic ablative interventions and included transurethral resection as one of the treatment arms. We excluded trials that reported on men without a clinical diagnosis of benign prostatic enlargement; comparisons with conservative management; and trials of interventions not involving tissue removal, such as transurethral incision. Table 1 lists the interventions considered (also see supplementary table 1 on bmj.com).

The primary outcome measure was change in symptom score at 12 months after surgery, measured by the international prostate symptom score or the American Urological Association symptom indexthese were considered equivalent and therefore we combined the results from trials using these instruments. The international prostate symptom score or American Urological Association symptom questionnaire asks men to rate four voiding symptoms (poor stream, intermittent flow, straining, incomplete emptying) and three storage symptoms (frequency, nocturia, urgency) on a scale from 0 (not present) to 5 (severe) to give a total score ranging from 0 to 35 , with severity of symptoms defined as mild (0-7), moderate (8-19), or severe (20-35).

Secondary outcomes were blood transfusion, urinary incontinence, urinary retention, urinary tract infection, loss of ejaculation, erectile dysfunction, quality of life, peak urine flow rate, duration of operation, length of hospital stay, and reoperation. We considered all reports of prespecified complications regardless of their timing. As separate reporting of bladder neck stenosis and urethral stricture was inconsistent we combined these complications.

\section{Validity assessment and data abstraction}

Two reviewers (TL, AC, or SW) independently assessed the methodological quality of the full text studies using an assessment tool drawing on the schema suggested by the National Health Service Centre for Reviews and Dissemination, ${ }^{3}$ Verhagen et al, ${ }^{4}$ Downs and Black, ${ }^{5}$ and the generic appraisal tool for epidemiology. Judgments on quality were based on the qualitative assessment of the number and type of criteria met by individual studies. 


\begin{tabular}{|c|c|c|c|}
\hline Outcome & No of trials & Relative risk $(95 \% \mathrm{CI})$ & $P$ value \\
\hline \multicolumn{4}{|c|}{ Holmium laser enucleation: } \\
\hline Loss of ejaculation & 2 & 1.14 (0.95 to 1.36$)$ & 0.15 \\
\hline Erectile dysfunction & 1 & NE & NE \\
\hline \multicolumn{4}{|l|}{ Laser vaporisation: } \\
\hline Loss of ejaculation & 5 & 0.22 (0.13 to 0.39$)$ & $<0.001$ \\
\hline Erectile dysfunction & 2 & 8.89 (1.29 to 61.37$)$ & 0.03 \\
\hline \multicolumn{4}{|c|}{ Transurethral vaporesection: } \\
\hline Loss of ejaculation & 2 & $1.16(0.85$ to 1.58$)$ & 0.35 \\
\hline Erectile dysfunction & 3 & $1.05(0.58$ to 1.81$)$ & 0.86 \\
\hline \multicolumn{4}{|c|}{ Bipolar tansurethral resection: } \\
\hline Loss of ejaculation & 1 & 0.93 (0.68 to 1.27$)$ & 0.64 \\
\hline Erectile dysfunction & 0 & - & - \\
\hline \multicolumn{4}{|c|}{ Transurethral vaporisation: } \\
\hline Loss of ejaculation & 6 & 0.78 (0.64 to 0.95$)$ & 0.01 \\
\hline Erectile dysfunction & 8 & $1.02(0.70$ to 1.47$)$ & 0.93 \\
\hline
\end{tabular}

The two reviewers recorded details of methodology, interventions, participants' characteristics, and outcomes on a data extraction form. Any differences that could not be resolved through discussion were decided by an arbiter. For trials with multiple publications we included only the most complete report for each outcome.

\section{Quantitative data synthesis}

For meta-analysis we combined data on dichotomous outcomes using the Mantel-Haenszel relative risk method. For continuous outcomes we used the inverse variance weighted mean difference method and 95\% confidence intervals. We intended to report results using a fixed effects model throughout, but we had to use a random effects model for symptom score and peak urine flow rate because of statistical heterogeneity, explored by $\chi^{2}$ tests and $\mathrm{I}^{2}$ statistics. We used the standard Cochrane software RevMan 4.2.8 for metaanalyses.

\section{RESULTS}

The initial search generated 3794 reports, of which 621 were selected for full assessment (see supplementary fig 1 on bmj.com). Eighty reports describing 45 trials met the eligibility criteria (table 1 ).

The 45 randomised controlled trials ${ }^{\mathrm{w1}-\mathrm{w} 45}$ were assessed as being of moderate or poor quality (see supplementary table 2 on bmj.com). Only six studies $(13 \%)$ explicitly stated that an intention to treat analysis was done and in three of these the analysis was compromised by failure to include all the participants in each arm at follow-up assessments. ${ }^{\text {w8w30 w45 }}$ The eligible randomised controlled trials included 47 relevant comparisons involving 3970 participants. Study setting and baseline characteristics of the patients, such as severity of the disease, varied across the included trials. Differences in outcome for bipolar transurethral vaporisation and bipolar transurethral vaporesection could not be assessed owing to lack of data.

Quantitative data synthesis

Symptom scores-The results from studies reporting changes in symptom score from baseline to 12 months showed significant heterogeneity, and hence random effect meta-analyses were done (fig 1). Larger mean changes were reported after holmium laser enucleation in all five trials with suitable data (weighted mean difference $-0.82,95 \%$ confidence interval -1.76 to $0.12 ; \mathrm{P}=0.09) .{ }^{\text {wl-w5 }}$ In contrast, of four trials on laser vaporisation ${ }^{\mathrm{w} 8 \mathrm{w} 11 \mathrm{w} 12 \mathrm{w} 15}$ three $^{\mathrm{w} 8 \mathrm{w} 11 \mathrm{w} 12}$ favoured transurethral resection $(1.49,-0.40$ to 3.39 ; $\mathrm{P}=0.12$ ). No evidence was found of differences for transurethral vaporesection, bipolar transurethral resection, or transurethral vaporisation. The seven trials with data that could not be included in the metaanalysis were consistent with these findings (see supplementary table 3 on bmj.com).

Peak urine flow rate-The results for peak urine flow rate at 12 months were generally consistent with those for symptom scores. Compared with transurethral resection of the prostate higher rates were reported for holmium laser enucleation (weighted mean difference $1.48 \mathrm{ml} / \mathrm{s}, 95 \%$ confidence interval 0.58 to 2.40 ; $\mathrm{P}=0.002)$ and lower rates for laser vaporisation $(-2.02 \mathrm{ml} / \mathrm{s},-4.75$ to $0.81 ; \mathrm{P}=0.15)$; overall, no differences were found after the other procedures, but heterogeneity was present between the individual trials (fig 2).

Quality of life-The quality of life of patients at 12 months after surgery was sparsely reported across the different interventions (see supplementary table 3 on bmj.com). When reported, quality of life was mainly rated using the international prostate symptom quality of life question score from 0 (good) to 6 (poor). No differences in improvements in quality of life scores were detected, but confidence intervals were wide.

Blood transfusion -Meta-analyses showed evidence of a lower rate of blood transfusion after holmium laser enucleation (relative risk $0.27,95 \%$ confidence interval 0.07 to $0.95 ; \mathrm{P}=0.04)$, laser vaporisation $(0.14,0.05$ to $0.42 ; \mathrm{P}=0.004)$, and transurethral vaporisation $(0.18$, 0.07 to $0.46 ; \mathrm{P}<0.001)$ compared with transurethral resection, whereas no significant difference was found for transurethral vaporesection and bipolar transurethral resection (fig 3). Combining data for all newer interventions showed an absolute risk reduction from $4.8 \%$ to $0.7 \%$.

Urinary retention -The risk of postoperative urinary retention requiring recatheterisation was higher after laser vaporisation and transurethral vaporisation than after transurethral resection $(11.3 \% v 3.8 \%$, relative risk $2.89,95 \%$ confidence interval 1.53 to $6.29 ; 8.9 \%$ v $2.5 \%$, $3.10,1.53$ to 6.29 , respectively), whereas no differences were seen with holmium laser enucleation and bipolar transurethral resection (fig 3). Data on transurethral vaporesection were insufficient for meta-analysis.

Strictures-The rate of strictures during follow-up after holmium laser enucleation, transurethral 
vaporesection, bipolar transurethral resection, and transurethral vaporisation was similar to that after transurethral resection. Strictures were less common after laser vaporisation (relative risk 0.54, 95\% confidence interval 0.32 to $0.90 ; \mathrm{P}=0.02$ ) than after transurethral resection, with a consistent effect seen in six ${ }^{\mathrm{w} 6-\mathrm{w} 9 \mathrm{w} 13 \mathrm{w} 14}$ of nine studies reporting this outcome (see supplementary figure 2 on bmj.com). In this comparison, eight of the $13(62 \%)$ strictures reported in the laser vaporisation group and 11 of the $27(41 \%)$ strictures reported in the transurethral resection group were bladder neck contractures (see supplementary fig 2 on bmj.com).

Incontinence-Men undergoing laser vaporisation had a higher risk of urinary incontinence (relative risk

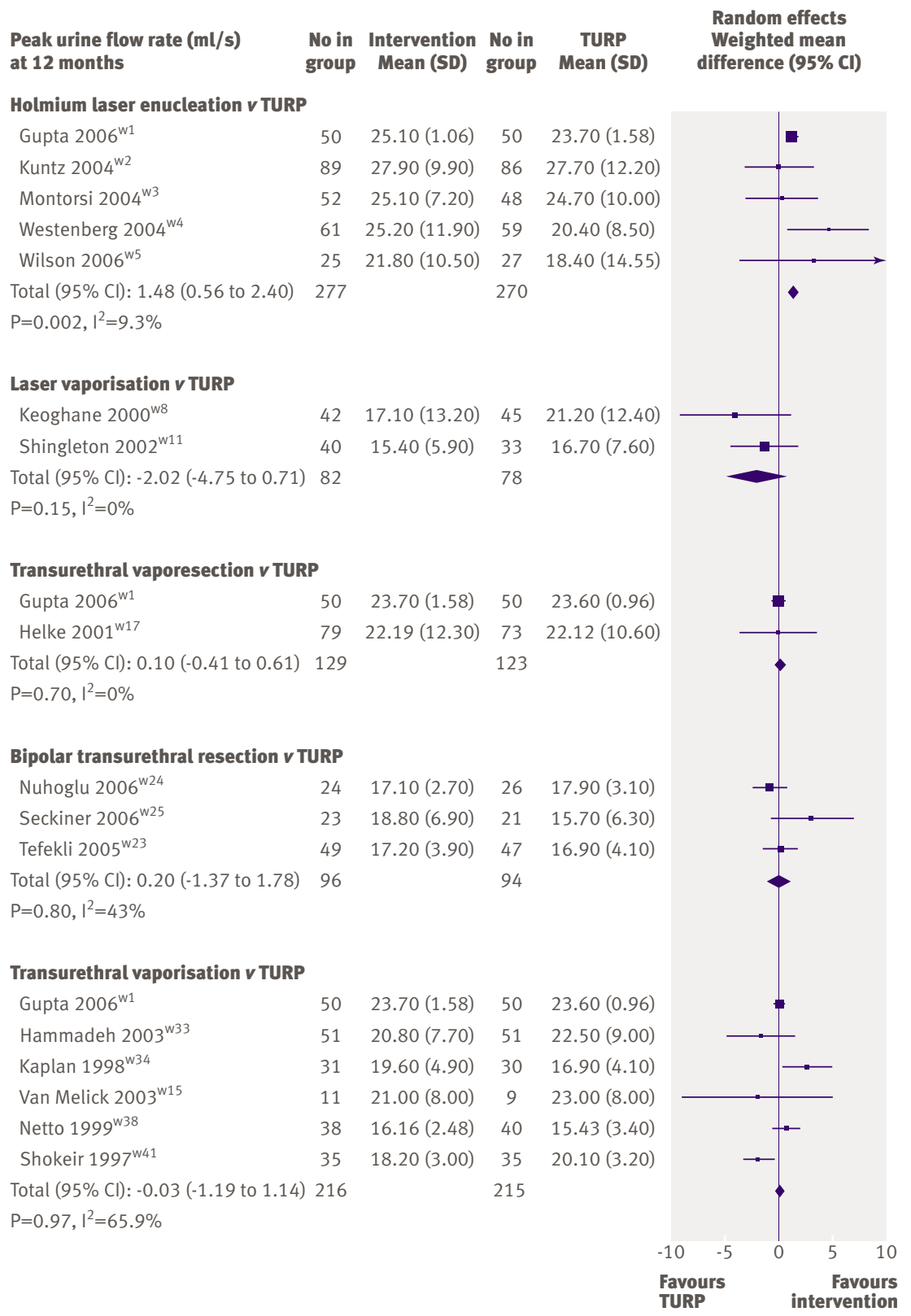

$\overline{\text { Fig } 2}$ | Meta-analyses of peak urine flow rate 12 months after end oscopic techniques for ablation of benign enlargement of prostate. TURP=transurethral resection of prostate
$2.24,1.03$ to $4.88 ; \mathrm{P}=0.04)$ but the difference was seen in only one trial, ${ }^{\text {w15 }}$ with high rates in both groups, and the type of incontinence was not fully described. For all the other interventions the occurrence of incontinence did not differ compared with transurethral resection (see supplementary fig 2 on bmj.com).

Urinary tract infection -No evidence was found of differences in the occurrence of postoperative urinary tract infection (see supplementary fig 2 on bmj.com).

Sexual dysfunction-Loss of ejaculation was less often experienced by sexually active men undergoing laser vaporisation (relative risk $0.22,0.13$ to $0.39 ; \mathrm{P}<0.001$ ) or transurethral vaporisation $(0.78,0.64$ to 0.95 ; $\mathrm{P}<0.01)$ than transurethral resection. The risk of erectile dysfunction was higher for sexually active men undergoing laser vaporisation $(8.89,1.29$ to 61.37), whereas the other interventions showed similar rates to transurethral resection (table 2). This result should be treated with caution as the confidence interval was large and therefore clinically important differences may have occurred between the two groups.

Descriptors of care- Of the assessed interventions only holmium laser enucleation showed a difference in duration of surgery compared with transurethral resection, taking on average 17 minutes longer $(95 \%$ confidence interval 13.45 to $20.47, \mathrm{P}<0.001)$. Hospital stay was shorter for all the interventions compared with transurethral resection, generally by one day or less (table 3). The need for a second procedure during follow-up was more common after laser vaporisation than after transurethral resection $(9.3 \% v 5.4 \%$; relative risk $1.68,95 \%$ confidence interval 0.97 to 2.63 ; $\mathrm{P}=0.04)$. No evidence was found of differences in reoperation rate between transurethral resection and the other ablative procedures, but confidence intervals were wide (table 3). Studies did not differentiate between further procedures to correct complications and those done for lack of efficacy.

\section{DISCUSSION}

In this systematic review we considered data from 3970 participants across 45 randomised controlled trials of moderate to poor quality. We found no evidence of a difference in outcomes for symptoms using any of the newer technologies for endoscopic ablation of benign enlargement of the prostate over transurethral resection at 12 months, although there was a trend favouring holium laser enucleation and against laser vaporisation. Patterns of improvement in peak urine flow rate were consistent with change in symptoms. Blood transfusion rates were higher for transurethral resection than for the newer methods, with the exception of bipolar transurethral resection. Men undergoing laser or diathermy vaporisation were more likely to experience urinary retention. Hospital stay was up to one day shorter for the newer technologies.

The randomised controlled trials identified by this review were not powered to detect differences in the low rates of mortality and major morbidity associated with transurethral resection of the prostate and 


\begin{tabular}{|c|c|c|c|}
\hline Outcome & $\begin{array}{l}\text { No of trials in meta- } \\
\text { analysis (total reporting } \\
\text { outcome) }\end{array}$ & Effect size $(95 \% \mathrm{Cl})$ & $P$ value \\
\hline \multicolumn{4}{|l|}{ Holmium laser enucleation: } \\
\hline Duration of operation & $5(5)$ & $16.96^{*}(13.45$ to 20.47$)$ & $<0.001$ \\
\hline Length of hospital stay & $4(4)$ & $-1.05^{\star}(-1.20$ to -0.89$)$ & $<0.001$ \\
\hline Reoperation & $4(4)$ & $0.68 \dagger(0.32$ to 1.44$)$ & 0.31 \\
\hline \multicolumn{4}{|l|}{ Laser vaporisation: } \\
\hline Duration of operation & $4(9)$ & $0.29^{\star}(-2.19$ to 2.78$)$ & 0.82 \\
\hline Length of hospital stay & $2(9)$ & $-1.39 *(-1.69$ to -1.10$)$ & $<0.001$ \\
\hline Reoperation & $9(9)$ & $1.68 \dagger(1.03$ to 2.74$)$ & 0.004 \\
\hline \multicolumn{4}{|l|}{ Transurethral vaporesection } \\
\hline Duration of operation & $2(2)$ & $1.06^{\star}(-8.70$ to 10.83$)$ & 0.83 \\
\hline Length of hospital stay & $1(1)$ & $-0.41 *(-0.54$ to -0.28$)$ & $<0.001$ \\
\hline Reoperation & $2(2)$ & $1.90 \dagger(0.80$ to 4.52$)$ & 0.15 \\
\hline \multicolumn{4}{|c|}{ Bipolar transurethral resection: } \\
\hline Duration of operation & $4(5)$ & $-4.56^{\star}(-15.36$ to 6.23$)$ & 0.41 \\
\hline Length of hospital stay & $1(2)$ & $-0.70 *(-1.37$ to -0.03$)$ & 0.04 \\
\hline Reoperation & $3(3)$ & $1.46 \dagger(0.25$ to 8.57$)$ & 0.67 \\
\hline \multicolumn{4}{|l|}{ Transurethral vaporisation: } \\
\hline Duration of operation & $8(14)$ & $-1.62^{\star}(-12.23$ to 8.99$)$ & 0.76 \\
\hline Length of hospital stay & $8(11)$ & $-1.00 *(-1.25$ to -0.75$)$ & $<0.001$ \\
\hline Reoperation & $7(7)$ & $1.04 \dagger(0.53$ to 2.07$)$ & 0.90 \\
\hline
\end{tabular}

therefore we have used proxy variables such as requirement for blood transfusion. Blood loss tends to be less well tolerated by elderly men with cardiac or renal comorbidity, which are common among men selected for transurethral resection. The significant reduction in the risk of transfusion seen with the newer techniques reflects better haemostatic properties of the energy sources used and is often perceived as their main advantage over standard monopolar diathermy. Although the relative risk reduction is considerable, the absolute benefit is small and its clinical importance could be challenged. The other key outcome was the need for reoperation as a result of complications, particularly stricture, or inadequate benefit for symptoms. The short term nature of the trials is a problem though, with rates equivalent to transurethral resection being documented at 12 months' follow-up probably reflecting treatment for complications rather than inadequate response. In this regard vaporisation procedures generally show slightly higher rates, which may become of more concern as such problems are likely to increase with longer observation. These studies do not tell us about the long term need for retreatment, which for transurethral resection is well characterised at between $0.5 \%$ and $1 \%$ per year of follow-up for up to 15 years. The risk of other complications that may cause permanent disability, such as incontinence and sexual dysfunction, do not seem to be substantially altered in the short term using the new technologies; however, confidence intervals were wide and important differences cannot be ruled out.
Another driver for change in countries with highly developed healthcare services is reduction in hospital stay. This is one area of achievement for the newer endoscopic treatments for clinical benign enlargement of the prostate, with an average saving of one bed day. This is likely to be positively received by patients and healthcare managers given the risks and costs of stays in hospital. It could be argued, however, that managed care pathways are shortening hospital stay for all procedures, including transurethral resection of prostate, and in consequence the cost saving for patients and healthcare providers may be small. ${ }^{6}$

\section{Strengths and limitations of the review}

We have used the best available methods to identify, review, and meta-analyse data available to us. Several limitations must be noted, however, when interpreting the results of this review. Heterogeneity in results for the primary outcome measure of reduction in symptom score presented problems in deriving a valid metaanalysis, which we overcame by using a random effects model. Clinical reasons for this heterogeneity include differences in baseline score for symptoms between studies and failure to control for other variables that may result in greater improvement in symptoms, such as initial prostate volume and the presence of urodynamic obstruction.

As with all secondary research it is possible to miss data owing to non-publication or non-appearance on the search strategy. A particular problem with the present review was that over half of the reports that met the initial inclusion criteria were only in abstract form. This made it impossible for us to assess all relevant data, and the exclusion of these studies prevented estimation of publication bias. The reasons why so many trials were reported only as abstracts were unclear and ideally should be investigated because publication bias in another setting accounted for up to $45 \%$ of an observed association, which may change the direction of effect. ${ }^{7}$

The moderate to poor methodological quality of the studies, together with the high number of comparisons, diluted the opportunities for meta-analysis. The confidence intervals around estimates of differences were often wide and this may have resulted in a failure to detect clinically important differences. ${ }^{89}$ The comparisons were against the standard of transurethra resection of prostate and therefore this limited our ability to assess how newer ablative treatments performed against each other. Study inclusion criteria such as prostate size also varied considerably between the trials, which questions the generalisability of the findings to everyday practice. This was exacerbated by variation and evolution in operative technique and treatment protocols between studies investigating the same basic technology. These variations were of particular concern for studies involving laser technology where there was variation in wavelength and power settings, together with site and duration of laser application. 
Blood transfusion

Holmium laser enucleation $v$ TURP

Gupta 2006 ${ }^{\mathrm{w} 1}$

Kuntz $2004^{\text {w2 }}$

Montorsi $2004^{\text {w3 }}$

Wilson $2006^{\text {w5 }}$

Westenberg $2004^{\mathrm{w} 4}$

Total ( $95 \% \mathrm{Cl}): 0.27$ (0.07 to 0.95)

Total events: 1 (Intervention), 9 (TURP)

$\mathrm{P}=0.04, \mathrm{I}^{2}=0 \%$

Laser vaporisation $v$ TURP

Bouchier-Hayes $2006^{\text {w6 }}$

Carter 1999w7

Keoghane $2000^{\text {w8 }}$

Van Melick $2003^{\text {w15 }}$

Mottet $1999^{\text {w9 }}$

Sengor $1996^{\text {w10 }}$

Shingleton $2002^{\mathrm{w} 11}$

Tuhkanen $2001^{\text {w13 }}$

Tuhkanen $2003^{\text {w14 }}$

Zorn $1999^{\text {w16 }}$

Total ( $95 \% \mathrm{Cl}): 0.14$ (0.05 to 0.42)

Total events: 1 (Intervention), 24 (TURP)

$P=0.0004, I^{2}=0 \%$

Transurethral vaporesection $v$ TURP

Helke $2001^{\text {w17 }}$

Kupeli $2001^{\text {w18 }}$

Liu $2006^{\text {w19 }}$

Talic $2000^{\text {w20 }}$

Total ( $95 \% \mathrm{Cl}$ ): 0.60 (0.24 to 1.49)

Total events: 7 (Intervention), 11 (TURP)

$\mathrm{P}=0.27, \mathrm{I}^{2}=0 \%$

Bipolar transurethral resection $v$ TURP

Nuhoglu $2006^{\text {w24 }}$

Tefekli $2005^{\text {w23 }}$

De Sio $2006^{\text {w21 }}$

Total (95\% Cl): 1.40 (0.32 to 6.20)

Total events: 3 (Intervention), 2 (TURP)

$\mathrm{P}=0.66, \mathrm{I}^{2}=0 \%$

Transurethral vaporisation $v$ TURP

Cetinkaga $1996^{\text {w27 }}$

Erdagi $1999^{\text {w29 }}$

Fowler $2005^{\text {w30 }}$

Galluci $1998^{\text {w31 }}$

Gotoh $1999^{\text {w32 }}$

Hammadeh $2003^{\text {w33 }}$

Kupeli $1998^{\text {w35 }}$

Kupeli $1998^{\text {w36 }}$

Van Melick $2003^{\text {w15 }}$

Nuhoglu $2006^{\text {w24 }}$

Patel $1997^{\text {w40 }}$

Total ( $95 \% \mathrm{Cl}$ ): 0.18 (0.07 to 0.46)

Total events: 2 (Intervention), 26 (TURP)

$P=0.0003, I^{2}=0 \%$

$$
\begin{array}{l|rrrr}
0.0010 .010 .1 & 0 & 10 & 1001000 \\
\begin{array}{l}
\text { Favours } \\
\text { intervention }
\end{array} & & \begin{array}{r}
\text { Favours } \\
\text { TURP }
\end{array}
\end{array}
$$

Urinary retention

Holmium laser enucleation $v$

TURP

Gupta $2006^{\text {w1 }}$

Kuntz 2004 ${ }^{\text {w2 }}$

Montorsi $2004^{\text {w3 }}$

Wilson $2006^{\text {w5 }}$

Westenberg 2004 ${ }^{\text {w4 }}$

Total ( $95 \% \mathrm{Cl}$ ): 0.71 (0.98 to 1.32)

Total events: 15 (Intervention), 21 (TURP)

$\mathrm{P}=0.28, \mathrm{I}^{2}=7.5 \%$

Laser vaporisation $v$

TURP

Carter $1999^{\text {w7 }}$

Keoghane $2000^{\text {w8 }}$

Van Melick $2003^{\text {w15 }}$

Shingleton $2002^{\text {w11 }}$

Tuhkanen $2001^{\text {w13 }}$

Total (95\% Cl): 2.89 (1.55 to 5.42)

Total events: 32 (Intervention), 11 (TURP)

$\mathrm{P}=0.0009, \mathrm{I}^{2}=0 \%$

Transurethral vaporesection $v$ TURP

Kupeli $2001^{\text {w18 }}$

Total events: 0 (Intervention), 0 (TURP)

\section{Bipolar transurethral resection $v$}

TURP

Nuhoglu $2006^{\text {w24 }}$

Tefekli $2005^{\text {w23 }}$

Total ( $95 \% \mathrm{Cl}): 1.71$ (0.24 to 12.38$)$

Total events: 2 (Intervention), 1 (TURP)

$\mathrm{P}=0.60, \mathrm{I}^{2}=0 \%$

Transurethral vaporisation $v$ TURP

Ekengren $2000^{\text {w28 }}$

Galluci $1998^{\text {w31 }}$

Hammadeh $2003^{\text {w33 }}$

Kupeli $1998^{\text {w35 }}$

Kupeli $1998^{\text {w36 }}$

Van Melick $2003^{\text {w15 }}$

Nuhoglu $2006^{\text {w24 }}$

Total $(95 \% \mathrm{Cl}): 3.10$ (1.53 to 6.29 )

Total events: 26 (Intervention), 8 (TURP)

$\mathrm{P}=0.002, \mathrm{I}^{2}=0 \%$

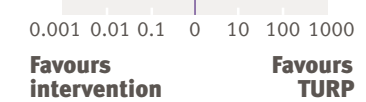

Fig 3 | Blood transfusion and urinary retention after endoscopic techniques for ablation of benign enlargement of prostate. TURP=transurethral resection of prostate 


\section{WHAT IS ALREADY KNOWN ON THIS TOPIC}

Transurethral resection of the prostate is the standard surgical procedure for benign prostatic enlargement

Transurethral resection provides a consistent, high likelihood of improvement, but is associated with relatively high risk of adverse events

A range of newer alternative ablative procedures has been tried in clinical practice

\section{WHAT THIS STUDY ADDS}

Newer ablative procedures for benign prostatic enlargement tested show similar improvement of symptoms as transurethral resection, with some evidence of fewer adverse effects

Holmium laser enucleation is a more promising alternative to transurethral resection but needs further evaluation some procedures such as transurethral vaporisation of the prostate have been abandoned despite a reasonable evidence base for their efficacy. In contrast, techniques using more recent technology such as bipolar transurethral resection and potassium-titanyl-phosphate laser vaporisation have now entered routine use without adequate published evidence of safety and cost effectiveness. In addition, the standard of transurethral resection of prostate has not stood still, with the improvements making the operation more uniform in outcome and less morbid in terms of adverse effects.

\section{Conclusions}

On the basis of current evidence it is not possible to reliably identify the most promising tissue ablative intervention for benign enlargement of the prostate. Transurethral resection of the prostate continues to be effective although it is associated with potentially significant morbidity. Of all the newer technologies assessed in this study, holmium laser enucleation seems to have the most promise. Nevertheless, the quality of the available evidence is poor and therefore research efforts in the management of benign prostatic enlargement should be concentrated on more efficient performance of higher quality, more rigorous, randomised controlled trials where outcomes and interventions are clearly defined and the timing of outcome measurement is registered. It is also essential that the reasons for reoperation are clearly stated, including when this decision is largely driven by patient choice.

We thank Bronwyn Davidson for secretarial support.

Contributors: TL coordinated the study, reviewed the effectiveness of the technologies, carried out data analyses, and wrote the manuscript. She is a guarantor. RB provided clinical advice and wrote the manuscript. LV and AG provided clinical or methodological advice and commented on drafts of the manuscript. CF developed and ran the search strategies and was responsible for obtaining papers and reference management. GM provided statistical support and advice. JN led and coordinated all aspects of the project, and is a guarantor. Other members of the Benign Prostatic Enlargement team contributed to development of review protocol, data abstraction, clinical content advice, and commented on analysis and interpretation of results. All authors declare that they accept full responsibility for the conduct of the study, had access to the data, and controlled the decision to publish. Other members of the Benign Prostatic Enlargement team are: Nigel Armstrong, Ghulam Nabi, Mark Deverill, Samuel McClinton, Susan Wong, Angela Coutts, and Graham Mowatt. Funding: Health Technology Assessment programme (project No 04/38/ 03). The Health Services Research Unit and the Health Economics Research Unit are core funded by the Chief Scientist Office of the Scottish Government Health Directorates. The views expressed in this paper are those of the authors not the institutions providing funding Competing interests: None declared.

Ethical approval: Not required

Provenance and peer review: Not commissioned; externally peer reviewed. standard deviation is required. ${ }^{13}$ It is possible that if means and standard deviations were reported more consistently, effect sizes would be different. This is another reason why adherence to consolidated standards of reporting trials guidelines for reporting of randomised controlled trials greatly aids the conduct of robust meta-analyses.

The usefulness of individual trial data together with systematic review is to some extent determined by the current context of patient care, which often changes before findings can be published. In the present case

1 Emberton M, Neal DE, Black N, Harrison M, Fordham M, McBrien MP, et al. The national prostatectomy audit: the clinical management of patients during hospital admission. Br J Urol 1995;75:301-16.

2 Mebust WK, Holtgrewe HL, Cockett AT, Peters PC. Transurethral prostatectomy: immediate and postoperative complications. A cooperative study of 13 participating institutions evaluating 3,885 patients. J Urol 1989;141:243-7.

3 Undertaking systematic reviews of research on effectiveness. CRD's guidance for those carrying out or commissioning reviews. CRD report No 4. University of York: Centre for Reviews and Dissemination, 2001.

4 Verhagen AP, de Vet HC, de Bie RA, Kessels AG, Boers M, Bouter LM, et al. The Delphi list: a criteria list for quality assessment of 
randomized clinical trials for conducting systematic reviews developed by Delphi consensus. J Clin Epidemiol 1998;51:1235-41.

5 Downs SH, Black N. The feasibility of creating a checklist for the assessment of the methodological quality both of randomised and non-randomised studies of health care interventions. J Epidemiol Community Health 1998;52:377-84.

6 Nakagawa T, Toguri AG. Early catheter removal following transurethral prostatectomy: a study of 431 patients. Med Princ Pract 2006;15:126-30.

7 Tweedie RL, Scott DJ, Biggerstaff BJ, Mengersen KL. Bayesian metaanalysis, with application to studies of ETS and lung cancer. Lung Cancer 1996;14:S171-94.

8 Newcombe RG. Towards a reduction in publication bias. BMJ 1987;295:656-9.

9 Thornton A, Lee P. Publication bias in meta-analysis: its causes and consequences. J Clin Epidemiol 2000;53:207-16.
10 Juni P, Altman DG, Egger M. Systematic reviews in health care: assessing the quality of controlled clinical trials. BMJ 2001;323:42-6.

11 Schulz KF, Chalmers I, Hayes RJ, Altman DG. Empirical evidence of bias. Dimensions of methodological quality associated with estimates of treatment effects in controlled trials. JAMA 1995;273:408-12.

12 Schulz KF. Assessing allocation concealment and blinding in randomised controlled trials: why bother? Evid Based Nurs 2001;4:4-6.

13 Wiebe N, Vandermeer B, Platt RW, Klassen TP, Moher D, Barrowman NJ. A systematic review identifies a lack of standardization in methods for handling missing variance data. J Clin Epidemiol 2006;59:342-53.

Accepted: 23 April 2008 